\title{
Deneysel Septik Şok Modeli Oluşturulan Ratlarda Eritropoetinin Karaciğer Dokusu Üzerine Etkisi
}

\author{
The Effects Of Erythropoietin On Liver Tissue In An Experimental Rat Model Of Septic Shock
}

\author{
Serdar ÖTER ${ }^{1}$, Adnan ŞAHIN ${ }^{1}$, Dilek BURUKOĞLU ${ }^{2}$, Emine SUTKEN ${ }^{3}$ \\ 'Eskişehir Osmangazi Üniversitesi Tıp Fakültesi Genel Cerrahi AD, Eskişehir, Türkiye \\ ${ }^{2}$ Eskişehir Osmangazi Üniversitesi Tıp Fakültesi Histoloji AD, Eskişehir, Türkiye \\ ${ }^{3}$ Eskişehir Osmangazi Üniversitesi Tıp Fakültesi Biyokimya AD, Eskişehir, Türkiye
}

Geliş Tarihi / Received: 01.10.2014

Kabul Tarihi / Accepted: 20.11.2014

\begin{abstract}
ÖZET
Giriş: Sepsis, inflamasyon ve enfeksiyon tablolarına karşı verilen sistemik bir yanıttır. Yoğun bakım ünitelerindeki en önemli ölüm sebeplerindendir.
\end{abstract}

Materyal-Methot: Bu çalışmada ratlarda çekal ligasyon ve perforasyon modeli ile oluşturulan deneysel septik şok modeli kullanarak eritropoetinin hepatik fonksiyonlar ve histolojik bulguları üzerindeki etkilerini araştırdık.

Bulgular: Eritropoetin uygulanan tedavi grubuna ait sIçanlarda tedavi sonrası AST ve ALT değerlerinde istatistiksel olarak anlamlı düzelme saptadık. Ayrıca eritropoietin ile tedavi edilen sıçanlardan karaciğerin histolojik yapısında istatistiksel olarak anlamlı düzelme saptadık.

Sonuç: Bu çalışmada septik şoktaki iskemi-perfüzyon hasarı ve inflamasyon tedavisinde eritropoetin kullandık. Veriler, septik şokun tedavisinde ve septik şoktan kaynaklanan karaciğer hasarında eritropoetin kullanımını önermektedir. Bu çalışmanın sonuçları, gelecekteki klinik çalışmaları teşvik edecektir. Eritropoetin, sepsis kaynaklı oksidatif hasardan organları korur gibi görünmektedir.

\section{ABSTRACT}

Background: Sepsis is a systemic response that develops against infection and inflammation. These disorders remain the most important cause of mortality in intensive care units.

Materal-Methods: In the present study, we used an experimental model of sepsis and septic shock by cecal ligation and perforation in rats to investigate the effects of erythropoetin on hepatic functions and liver histology.

Findings: After treatment, we found statistically significant improvement in AST and ALT values at Erythropoietin treatment group. Also statistically significant improvements were observed in histological findings of liver in rats treated with erythropoetin.

Results: In this study, we used erythropoietin to treat the septic shock and ischemia-perfusion injury and inflammation. Data suggest that erythropoetin for the treatment of septic shock, as well as the liver damage resulting from the septic shock. Results of this study should prompt future clinical studies. It seems likely that erythropoetin protects the organs against sepsis-induced oxidative organ injury.

Key words: erythropoetin, sepsis, rat, liver

Anahtar kelimeler: Eritropoetin, sepsis, fare, karaciğer 


\section{GíRiş}

Sepsis, inflamasyon ve enfeksiyon tablolarına karşı verilen sistemik bir yanıttır. Yoğun bakım ünitelerindeki en önemli ölüm sebeplerindendir (1). Şok bulguları da bu tabloya eşlik ettiği durumlarda mortalite oranı artmaktadır (2). Sepsis ve septik şokta mortalite \% 30-70 arasında değişmektedir (3).

Eritropoietin (EPO) 30,4 kDA moleküler ağırlığa sahip glikoprotein yapıda esas olarak böbreklerden salgılanan bir hormon olup, memelilerde eritropoezi düzenlediği uzun yıllardır bilinmektedir $(4,5)$. EPO, renal peritübüler interstisyel hücreler, hepatositler ve kupffer hücreleri tarafından sentezlenmektedir $(4,6)$. Kemik iliği içerisinde eritroid progenitör hücreleri uyararak eritrositlerin farklılaşmasını sağlar ve oksijen taşıma kapasitesini artırır. Ancak son yıllarda yapılan çalışmalarda anti-apopitotik ve anti-iskemik özelliklerinden dolayı genel olarak doku koruyucu bir ajan olarak değerlendirilmektedir (7). EPO progenitör kök hücre gelişmesinde, hücresel integritenin devamında ve anjiogeneziste de etkilidir. Birçok çalışma eritrosit üretiminden öte beyin, böbrek, karaciğer ve kalp gibi dokuları iskemi reperfüzyona bağlı oluşan hasarlarda korumada etkili olduğunu göstermiştir (8).

Bu çalışmada ratlarda çekal ligasyon ve perforasyon modeli ile oluşturulan deneysel septik şok modelinde rekombinant DNA teknolojisiyle geliştirilen bir hormon olan eritropoetinin hepatik fonksiyonlar üzerine septik şokun klinik, laboratuvar ve histolojik bulguları üzerindeki etkilerini araştırmayı amaçladık.

\section{GEREÇ ve YÖNTEM}

Bu deneysel çalışma Eskisehir Osmangazi Üniversitesi etik kurul komitesinden onay alınarak Eskisehir Osmangazi Üniversitesi Tıp Fakültesi Biyokimya bölümü araştırma laboratuvarı, Fizyoloji bölümü araştırma laboratuvarı, ve Tıbbi Araştırma Merkezi Deney Hayvanları Laboratuarında "Guide for the Care and Use of Laboratory Animals" prensipleri doğrultusunda hayvan hakları korunarak yapıldı.

Hayvanlar ve Diyet: Çalışmada; Eskişehir Os- mangazi Üniversitesi Tıp Fakültesi Etik Kurulu onayı alınarak TiCAM laboratuarından elde edilen ve ağırlıkları 200-300 gr arasında değişen 24 adet Spraque- Dawley cinsi rat kullanıldı. Ratlar-da cinsiyet ayrımı gözetilmedi. Hayvanlar deney süresince standart laboratuar koşullarında, oda sıcaklığında korundular, standart rat yemi ve musluk suyu ile beslendiler.

Deneysel Protokol: Tüm ratlara 12 saatlik açlığı takiben intraperitoneal $60 \mathrm{mg} / \mathrm{kg}$ Ketamin Hidroklorür (parke Davis) ve $5 \mathrm{mg} / \mathrm{kg}$ Xylazin (Bayer) anestezisi uygulandı. Anestezi derinliği; intraperitoneal enjeksiyondan $5 \mathrm{dk}$ sonra bir dişli pensetle karın cildi sıkıştırılıp ağrılı uyarana verdiği yanıt kontrol edilerek tespit edildi.

Steril koşullarda steril malzemeler kullanılarak \%10 luk povidon İyodin (Drog-san) temizliğini takiben 24 adet rat'a sol inguinal bölge derisine uygulanan insizyonla femoral arter ve femoral venleri izole edilerek pig tail 60 (polietilen) kateter vasıtası ile kateterize edildi. Femoral ven kateteri vena kavaya kadar ilerletilerek tespit edildi. Kanülasyon işlemi yapılmadan önce ve sonra, kanüller $100 \mathrm{iÜ/} \mathrm{ml}$ heparin içeren fizyolojik serum solüsyonları ile yıkanarak tıkanmaları önlendi. Kateterlerin ucu kapatılarak subkutan tünel vasıtasıyla enseden çıkartıldı. Cerrahi prosedür ve takip esnasında hipotermiden kaçınmak için bütün hayvanlar 36, 6 derecede Isıtılmış cerrahi masada opere edildiler. Ratlarda deney sırasında mortalite gözlenmedi.

Ratlar randomize olarak üç gruba ayrıldıktan sonra kateterizasyon işleminden en geç 24 saatte olmak üzere;

Grup 1 (Kontrol grubu): Bu gruptaki 8 adet rat' a anesteziyi takiben mesane kanülasyonu uygulandı. Postoperatif idrar takibi ile birlikte 14. saatten itibaren invaziv tansiyon ve EKG kayıtları alındı 5 dakika aralıklarla vital bulguları kaydedildi. Kateterizasyon işleminden önce ve deney sonunda biyokimyasal ölçümler (İşlem öncesi: Aspartat aminotransferaz 1 (AST1), Alanin aminotransferaz 1 (ALT1), işlem sonrası: AST2, ALT2) için kan örnekleri alındı. Kanda ve karaciğer dokusunda Melandialdehit (MDA) ölçümü için kan ve doku örnekleri alındı. Ratlar 24. saat sonun- 
da aşırı ketamin anestezisi ile sakrifiye edildikten sonra histopatolojik inceleme için karaciğer dokusundan örnekler alındı.

Grup 2 (Sepsis grubu): Bu gruptaki 8 rat' a anesteziyi takiben laparotomi ve çekal ligasyon perforasyon (ÇLP) uygulandı. Mesane kanülasyonu uygulandı. Kan örnekleri birinci gruptakine benzer şekilde alındı. Postoperatif, 14. saatten itibaren invaziv TA takiplerinde $90 \mathrm{mmHg}$ ' nın altına tansiyon değerlerinin düşmesi veya ilk ölçülen tansiyon değerlerinden $40 \mathrm{mmHg}$ ve daha fazla tansiyon düşmesi septik şok için anlamlı kabul edildi. $10 \mu \mathrm{gr} / \mathrm{dk}$ Salin infüzyonu başlandı. Ratlara 24 saatin sonunda 1. Gruptaki gibi kan ve doku örnekleri alınarak aşırı doz ketamin anestezisi altında sakrifiye edildi.

Grup 3 (Tedavi grubu): Bu gruptaki 8 rat'a 2. gruptaki gibi laparotomi çekal ligasyon perforasyon ve septik şok oluşturulduktan sonra kan örnekleri alındı. Çekal ligasyon perforasyon işleminden 60 dakika sonra $4000 \mathrm{lU} / \mathrm{kg}$ Eritropoetin subkutan yolla tek doz bolus verilerek hemodinamik yanıtları kaydedildi. Arter basınçları basınç transdüseri (Transpac IV, USA) ile ölçüldü.

Ratların invaziv arter basınçları ve kalp atım hızları Data Equationsystem (MP 100 Biopac USA) aracılığı ile monitörize edildi.

Başlangıç ve sonuç, hemogram ve biyokimyasal ölçümleri üniversitemizin hematoloji ve biyokimya bilim dallarında standart yöntemlerle uygulandı. Karaciğer dokusunda ve kanda MDA ölçümleri hastanemiz biyokimya anabilim dalında, karaciğer dokusundan alınan örneklerin histopatolojik incelemesi hastanemiz histoloji anabilim dalında değerlendirildi.

Ratların vücut ısıları rektal prop yardımıyla ölçülerek başlangıç ve sonuç değerleri kaydedildi.

\section{Serum ve Dokuda Melandialdehit (MDA) Ölçümü}

Doku örneklerinin her biri hassas terazile tartılarak 0,15 Mol KCL solüsyonu içinde 1:10 homojenize edilmiştir. Homojenatlar 4000 rpm'de 10 $\mathrm{dk} .,+4^{\circ} \mathrm{C}$ 'de santrifüj edilerek supernatantlarda MDA ölçümü gerçekleştirildi. 0,4 ml superna- tant başına 1,5 ml TBA (\%0,08' lik ph:5,5), 1,5 $\mathrm{ml}$ asetik asit (\%20'lik ph:3.5) ve $0,2 \mathrm{ml} \% 8.1^{\prime}$ lik sodyum dodesil sülfat eklenerek karıştırılmıştır. MDA standartları stok MDA standartlarından taze olarak hazırlanmıştır. Tüm örnekler ve standartlar karıştırıldıktan sonra $100{ }^{\circ} C^{\prime}$ de 1 saat kaynatılmıştır. Süre sonunda örnekler ve standartlar soğuk su ile soğutulup $5 \mathrm{ml} \mathrm{n}$ - butanol her birine eklenmiştir.Her bir tüp 4000 rpm' de $10 \mathrm{dk}$ santrifüj edildi.Üzerlerindeki berrak sIVı alınıp örnek ve standartların absorbansları 532 $\mathrm{nm}^{\prime}$ de kendi körüne karşı spektrofotometrede okutulmuştur. "Plazma MDA ölçümünde de süpernatan elde edildikten sonra yapılan tüm işlemler plazma için de uygulanmıştır".

\section{Histolojik Yöntemler}

Alınan karaciğer örneklerinin \% 10'luk formalin fiksatifi içinde 48 saat süre ile fiksasyonları sağlandı. Fiksasyonları sağlanan örnekler fiksatifin çökmesini engellemek amacıyla 3-4 saat çeşme suyunda yıkandı. Çeşme suyuyla yıkanan doku parçaları daha sonra sırasıyla kademeli olarak \%70' lik, \%80' lik, \%90'lık ve \%96' lık alkol serilerinde $45^{\prime}$ er dakika bekletilerek dehidratasyonları sağlandı. Dehidratasyonlarının ardından örnekler şeffaflandırılmak üzere $2 \mathrm{kez}$ 20'şer dakika ksilolde bekletildi. Karaciğer örnekleri şeffaflanmalarının ardından etüv içinde $650 C^{\prime}$ de eritilmiş parafinlere alınarak 60 dakika süreyle üç ayrı parafinde bekletildi. Parafinize edilen dokular ayrı ayrı parafin içeren kasetlere gömülerek bloklandı ve kesit alınmaya hazır duruma getirildi. Mikrotom aracılığı ile her bir örnekten 5'er mikrometre kalınlığında doku ke-

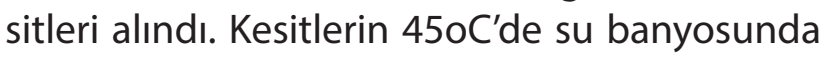
açılmaları sağlanarak temiz lamlar üzerine alınmasından sonra etüv içinde 1 saat süre ile bekletilmeleri sağlandı. Preparatlar 1'er saat süre ile iki ayrı ksilolde tutulup deparafinizasyonları sağlandıktan sonra boyama aşamasına geçildi. Kesitlerin boyanmasında Hematoksilen- Eosin ikili boyası kullanıldı. Deparafinizasyonu yapımış olan doku kesitleri 5'er dakika süreyle $\% 96$, $\% 90, \% 80, \% 70$ 'lik alkollerde ve distile suda bekletildi. Kesitler Hematoksilen ile 2 dakika ve Eosin ile 10 dakika boyandı. Çeşme suyu ile fazla boyası alınan kesitler hızla alkol serilerinden geçirilip dehidratasyonları sağlandı. Dokular iki ayrı ksilolde 30'ar dakika tutularak şeffaflaştırıl- 
dı ve şeffaflanan dokular daha sonra entellan ile kapatılarak ışık mikroskobik düzeyde Olympus BH-2 mikroskop ile değerlendirmeleri yapıldı ve karaciğer ve böbrek örneklerini içeren tüm preperatların Olympus DP-70 digital kamera ile fotoğrafları çekildi.

\section{İstatistiksel Değerlendirme}

İstatistiksel değerlendirme hastanemiz Biyoistatistik Anabilim dalı laboratuarında yapıldı. Çalışmada SPSS 13.0 ve Sigma Stat 3.1 paket programlar kullanılmıştır.Üç gruba ait normal dağılım gösteren Ölçümsel değişkenlerimizin değerlendirilmesinde One Way Analysis of Variance Testi yapılmış olup bu testin çoklu karşılaştırmalarında (Fisher LSD Method, Tukey Test) metodundan yararlanılmıştır. Öncesi - sonrası değişkenlerin ikili karşılaşrılmalarında eşleştirilmiş t testi (Pairt Samples Statistics). Normal dağılım göstermeyen 3 gruba ait değişkenlerin karşılaştırılmasında Kruskal-Wallis One Way Analysis of Variance on Ranks, öncesi - sonrası değişkenlerin ikili karşılaşrırmalarında Wilcoxon Signet Rank Testlerinden yararlanılmıştır.

\section{BULGULAR}

Ratların ağırlıkları kontrol grubunda (grup1) ortalama 252,134 ( \pm 14$)$ gr, çekal ligasyon perforasyon (sepsis) grubunda (grup2) 258,3734 $( \pm 13)$ gr ve çekal ligasyon perforasyon + eritropoetin (tedavi) grubunda (grup3) 261,165 ( \pm 16 ) gr olarak bulundu. Gruplar arasında istatistiksel olarak anlamlı farklılık bulunmamaktadır $(P \geq 0,05)$.

\section{Hepatik Fonksiyonlar, Doku ve Serum MDA Düzeyleri}

AST1 ve ALT1 düzeyleri deney başlangıcında AST2vve ALT2 düzeyleri deney sonunda tüm gruplarda çalışıldı ve tablo 1'de sunuldu. Deneyin sonunda karaciğer dokusundan alınan örneklerden ve serum örneklerinden çalışılan MDA düzeyleri; MDADOKU ve MDAPL olarak isimlendirilerek çalışıldı ve tablo 1 de sunuldu. MDAPL değerlerinde gruplar arasında istatistiksel olarak anlamlı farklılık mevcuttu $(P \leq 0,001)$. Grup1 ile grup2, grup2 ile grup3 ve grup1 ile grup3 arasında istatistiksel olarak anlamlı farklılık mevcuttu $(P \leq 0,001)$. MDADOKU değerlerinde gruplar arasında istatistiksel olarak anlamlı farklılık mevcuttu $(P \leq 0,001)$. Grup1 ile grup2 , grup2 ile grup3 arasında istatistiksel olarak anlamlı farklılık mevcuttu ( $P \leq 0,001)$. Grup1 ile grup3 arasında istatistiksel olarak anlamlı farklılık saptanmadı $(P \geq 0,05)$. AST1 ve ALT1 değerlerinde gruplar arasında istatistiksel olarak anlamlı farklılık saptanmadı $(P \geq 0,05)$. ALT2 değerlerinde gruplar arasında istatistiksel olarak anlamlı farklılık mevcuttu $(P \leq 0,001)$. Grup1 ve grup2 ve grup1 ile grup 3 arasında istatistiksel olarak anlamlı farklılık mevcuttu $(P \leq 0,001)$. Grup2 ile grup3 arasında istatistiksel olarak anlamlı farklılık saptanmadı $(P \geq 0,05)$. AST2 değerlerinde gruplar arasında istatistiksel olarak anlamlı farkIılık mevcuttu $(P \leq 0,001)$. Grup1 ve grup2 arasında istatistiksel olarak anlamlı farklılık mevcuttu $(P \leq 0,001)$. Grup1 ile grup 3 ve grup2 ile grup3 arasında istatistiksel olarak anlamlı farklılık saptanmadı $(P \geq 0,05)$ (Tablo-1).

Tablo 1: Gruplardaki hepatik fonksiyonların ve Gruplar arasında doku ve plazma MDA değerlerinin seyri.

(Grup-1: Kontrol grubu, Grup-2: Sepsis grubu, Grup-3: Tedavi grubunu göstermektedir. MDADOKU: Deney sonunda dokudaki MDA düzeyi, MDAPL: Deney sonunda plazmadaki MDA düzeyi, AST: Aspartat amino transferaz, ALT: Alanin amino transferaz), (AST1 ve ALT1: deney başlangıcındaki değerler; AST2 ve ALT2 deneyin sonundaki değerleri göstermektedir). İstatistiksel olarak anlamlı değer: $P \leq 0,01$

\begin{tabular}{|c|c|c|c|c|}
\hline & Grup 1 & Grup 2 & Grup 3 & P \\
\hline AST1 & $37,5 \pm 5,63$ & $35,12 \pm 6,87$ & $35,37 \pm 5,9$ & $P \geq 0,05$ \\
\hline AST2 & $50,37 \pm 9,55$ & $383,87 \pm 17,56$ & $230,62 \pm 12,6$ & $P \leq 0,001$ \\
\hline ALT1 & $21,5 \pm 4,1$ & $20,37 \pm 6,25$ & $21,5 \pm 7,01$ & $P \geq 0,05$ \\
\hline ALT2 & $35,37 \pm 5,97$ & $168,5 \pm 52,05$ & $127 \pm 44,62$ & $P \leq 0,001$ \\
\hline MDADOKU & $11,45 \pm 1,64$ & $20,23 \pm 1,94$ & $13,4 \pm 1,08$ & $P \leq 0,001$ \\
\hline MDAPL & $2,41 \pm 0,66$ & $7,78 \pm 1,42$ & $4,2 \pm 0,63$ & $P \leq 0,001$ \\
\hline
\end{tabular}




\section{Histolojik Bulgular}

Kontrol grubuna ait sıçan karaciğerleri üzerinde ışık mikroskobik olarak yapılan incelemelerde karaciğer hepatosit hücreleri, vena sentralis yapısı, portal alan ve sinüzoidal kapiller yapıları normal histolojik yapıda gözlendi. (Şekil-1)

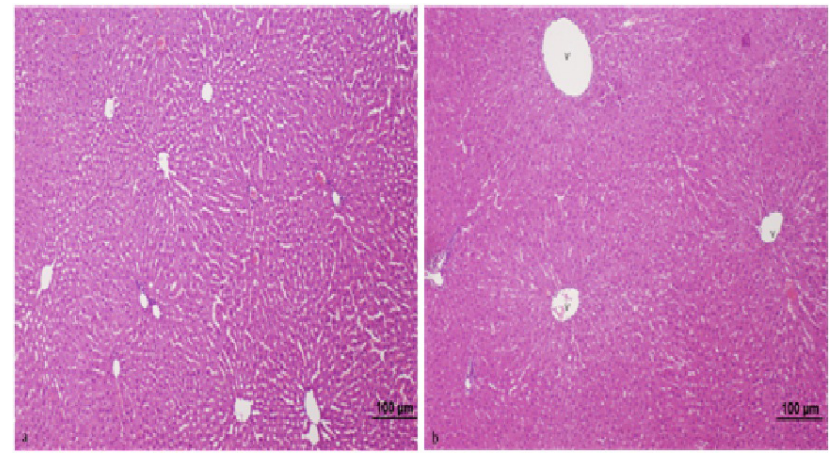

Şekil 1: Kontrol grubu karaciğer dokusu; ışık mikroskobik olarak yapılan incelemelerde karaciğer normal histolojik yapıda gözlendi (a) (x4, HE).

Çekal ligasyon ile septik şok uygulanan Sepsis grubuna ait sıçanlardan alınan karaciğer örneklerinde ışık mikroskobik olarak yapılan incelemelerde özellikle sinüzoidal dilatasyonlar ve portal alanda hücresel inflamasyon gözlendi. Ayrıca karaciğer hepatosit hücre nükleuslarında hipertrofi dikkat çekti. (Şekil-2)

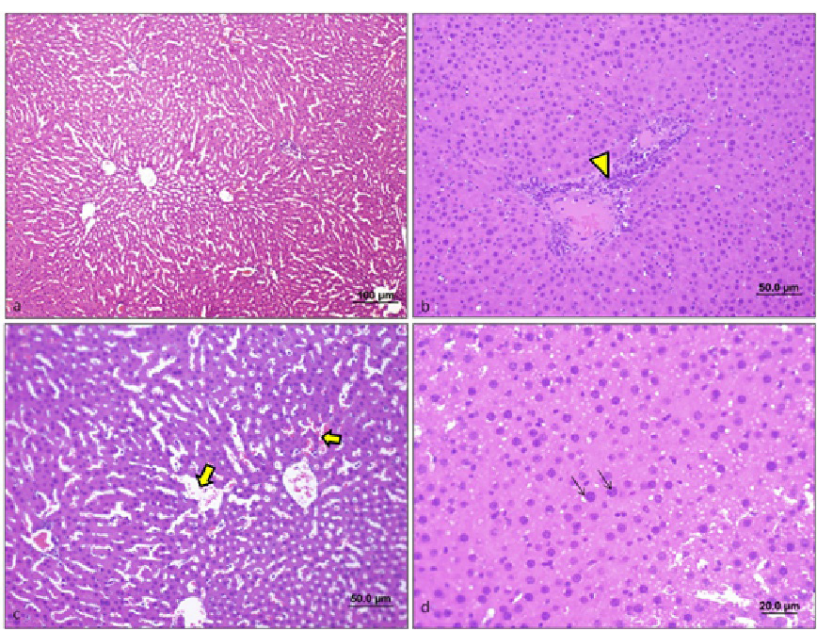

Şekil 2: Sepsis grubu karaciğer dokusu; çekal ligasyon ile septik şok uygulanan bu grubun karaciğer örneklerinde ışık mikroskobik olarak yapılan incelemelerde sinüzoidal dilatasyonlar (kalın ok) $(\mathrm{a}, \mathrm{c})(\mathrm{x} 4,20, \mathrm{HE})$, portal alanda yoğun hücresel inflamasyon (ok başı) (b) (x10, HE) ve nekrotik hücre yapıları ve hepatosit hücre nükleuslarında hipertrofi gözlendi (ok) (d) (x 40, HE) dikkat çekti.

Septik şok+eritropoetin uygulanan tedavi grubuna ait sıçanlardan alınan karaciğer örneklerinde ışık mikroskobik olarak yapılan incelemeler- de özellikle kontrol grubuyla karşılaştırıldığında sinüzoidal dilatasyonun ve portal alandaki hücresel inflamasyonun oldukça azalmış olduğu ve karaciğerin normale yakın histolojik yapıda olduğu görüldü. (Şekil-3) ve (Tablo-2).

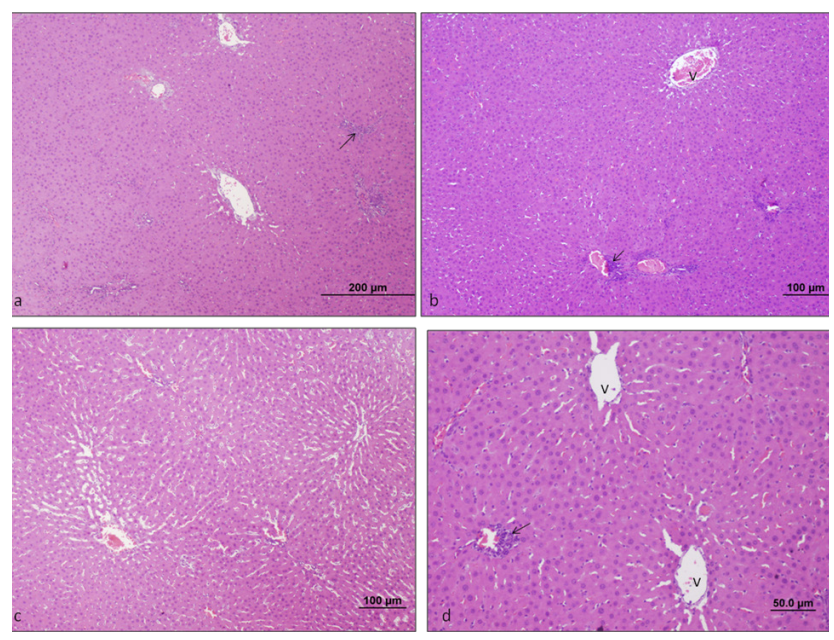

Şeki 3: Tedavi grubu karaciğer dokusu; septik şok+ eritropoetin uygulanan bu grubun karaciğer örneklerinde Işık mikroskobik olarak yapılan incelemelerde sinüzoidal dilatasyonun ve portal alandaki hücresel inflamasyonun oldukça azalmış olduğu $(a, b, c, d)(x 10,20, H E)$ ve karaciğerin normale yakın histolojik yapıda olduğu görüldü.

Tablo 2: Çalışma sonunda ratlardan alınan karaciğer doku örneklerinin ışık mikroskobik incelemesi ; histolojik sonuçları. ((-) hasar yok, (+) az hasar, (++) orta hasar, (+++) hasar çok olarak değerlendirilmiştir.

\begin{tabular}{|c|c|c|c|c|}
\hline & & DiLATASYON & & \\
\hline Kontrol Grubu 1 & - & - & - & - \\
\hline Kontrol Grubu 2 & - & - & - & - \\
\hline Kontrol Grubu 3 & - & - & - & - \\
\hline Kontrol Grubu 4 & + & - & - & - \\
\hline Kontrol Grubu 5 & - & - & - & - \\
\hline Kontrol Grubu 6 & - & - & - & - \\
\hline Kontrol Grubu 7 & - & - & - & - \\
\hline Kontrol Grubu 8 & - & - & - & - \\
\hline Sepsis Grubu 1 & - & +++ & ++ & - \\
\hline Sepsis Grubu 2 & + & ++ & - & - \\
\hline Sepsis Grubu 3 & - & ++ & - & + \\
\hline Sepsis Grubu 4 & - & - & +++ & - \\
\hline Sepsis Grubu 5 & ++ & - & - & + \\
\hline Sepsis Grubu 6 & - & - & ++ & - \\
\hline Sepsis Grubu 7 & + & - & + & - \\
\hline Sepsis Grubu 8 & - & +++ & - & ++ \\
\hline Tedavi Grubu 1 & - & - & - & + \\
\hline Tedavi Grubu 2 & - & - & + & + \\
\hline Tedavi Grubu 3 & - & - & + & - \\
\hline Tedavi Grubu 4 & - & + & + & + \\
\hline Tedavi Grubu 5 & - & - & + & - \\
\hline Tedavi Grubu 6 & - & - & - & - \\
\hline Tedavi Grubu 7 & - & - & + & + \\
\hline Tedavi Grubu 8 & - & - & - & - \\
\hline
\end{tabular}




\section{TARTIŞMA}

Günümüzde kullanılmaya başlanan yeni antibiyotikler, ilaçlar ve immünmodülasyona yönelik tedavi protokollerine rağmen, septik şok, \%3090 ölüm oranı ile kendini gösteren, ciddi bir sağlık problemi olmaya devam etmektedir $(3,9)$. EPO, ilk olarak kemik iliği ve ekstramedüller alanlarda eritrosit oluşumunu sağlayan glikoprotein yapılı. bir hormon olarak keşfedilmiş ancak son yıllarda eritopoetik etkisi dışında genel doku koruyucu özelliği ortaya konmuştur. EPO çeşitli nedenlerden ötürü gelişen anemi tedavisinde yaygın olarak kullanılmaktadır. Kronik böbrek yetmezlikli hastalarda anemi tedavisinde kullanılan EPO'in egzersiz toleransını arttırdığı, kardiyak outputu düzelttiği, periferik vasküler direnci arttırdığı, angina semptomlarını gerilettiği, myokardiyal iskemiyi azalttığı, ventriküler hipertrofiyi azalttığı belirtilmiştir (10). Bunun yanı sıra beyin fonksiyonlarını arttırdığı, üremik kanamaya meyli azalttığı, trombosit fonksiyonlarını arttırdığı, cinsel fonksiyonları arttırdığı, endokrin ve immün sistemi düzelttiği ve hayat kalitesini arttırdığı yapılan çalışmalarla ortaya konmuştur (11).

Vedat B. ve ark. torsiyon/detorsiyon yöntemiyle iskemi reperfüzyon hasarı oluşturulan ratlarda eritropoetinin özellikle akut dönemde başarılı sonuçlar sağladığını ve MDA değerlerinde olumlu etkilerde bulunduğunu göstermişlerdir (12).

Çalışmamızda da her üç gruptan alınan çalışma öncesi AST ve ALT değerlerinde anlamlı farklılık yok iken çalışma sonundaki AST ve ALT değerlerinde üç grupta da istatiksel olarak anlamlı sonuçlar elde edilmiştir. Burada dikkati çeken eritropoetin verilen tedavi grubundaki değerlerin kontrol grubuna göre daha iyi ve düşük bulunmasıdır. Aynı şekilde karaciğer dokusundan ve kandan çalışılan MDA değerlerinin eritropoetin verilen tedavi grubunda daha olumlu saptanmasıdır.

Deney sonunda üç gruptaki ratların karaciğer dokularından alınan doku örneklerinin histolojik incelemesinde; eritropoetin verilen tedavi grubuna ait sıçanlardan alınan karaciğer örnek- lerinde özellikle kontrol grubuyla karşılaştırıldığında sinüzoidal dilatasyonun ve portal alandaki hücresel inflamasyonun oldukça azalmış olduğu ve karaciğerin normale yakın histolojik yapıda olduğu görüldü.

M.Bockhorn ve ark. hepatik rejenerasyon modelinde eritropoetini kullanmış olup transplante edilen karaciğer dokularında eritropoetin verilen grupta olumlu sonuçlar almışlardır (13). Sepodes M. Maio R. Ve ark. ratlarda karaciğer iskemi-reperfüzyon hasarında eritropoetinin etkili olduğunu çalışmalarında göstermişlerdir (14). Yaptığımız çalışmada da eritropoetin verilen tedavi grubundaki AST, ALT, MDA değerlerinde ve karciğer dokusunda bu ve buna benzer çalışmalara paralel olarak anlamlı derecede başarılı sonuçlar alınmıştır (15).

Rocha J ve ark.'nın yaptığı çalışmada sıcak sıvı yanıklı hastalarda verilen eritropoietinin akut akciğer hasarında ve sitoprotektif olumlu etkileri olduğunu göstermişlerdir (16). Ayrıca Mesut G. ve ark. parsiyel hepatektomi sonrasında yüksek doz epo verilmesinin karaciğer fonksiyon testlerinde düzelmeye yol açtığını ve karaciğerde rejenerasyonu arttırdığını göstermişlerdi (17). Nandra K.K ve ark.' nın yaptıkları bir çalışmada deneysel hemorajik şok oluşturmadan 3 gün önce başlanan epo tedavisi uygulanmasının renal, nöromusküler ve hepatik fonksiyonlardaki bozulmayı azalttığını göstermişlerdir (18).

Bu çalışmada ideal bir deneysel septik şok modeli halen ortaya konulamamasına rağmen klinik uygulamaya benzer bir model uygulamaya özen gösterdik. Yaptığımız araştırmalarda septik şoktaki iskemi-perfüzyon hasarı ve inflamasyon için olan tedavi arayışlarına oldukça etki alanı çeşitli ve güçlü olan eritropoetin gibi bir ajanı kullandık. Biokimyasal, klinik ve histolojik bulgularda oldukça olumlu sonuçlarla karşılaştık. Bu deneysel çalışmada özellikle de erken dönemde uygulanan eritropoetin ile elde edilen olumlu sonuçların daha ilerde yapılacak klinik çalısmalara yön vereceğini ve eritropoetinin yeni bir çok alanda daha kullanılabilirliğinin yeni çalışmalarla ortaya konabileceğini düşünüyoruz. 


\section{KAYNAKLAR}

1. Alberti $C$, Brun-Buisson $C$, Burchardi $H$, et al. Epidemiology of sepsis and infection in ICU patients from an international multicentre cohort study. Intensive Care Med. 2002; 28: 108-21.

2. Matot I, Sprung CL. Definition of sepsis. Intensive Care Med. 2001; 27: 3-9.

3. Hines DW, Bone RC. Septic Shock. In: Gorbach SL, Bartlett JG, Blacklow NR(eds). Infectious Diseases. Second Edition. W.B. Saunders Co., Philadelphia, 1992; 544-48.

4. Krantz SB. Erythropoietin. Blood 1991; 77: 419-34.

5. Woodman D.D.: Erythropoetin, Comparative Haematology International; 1992; 2: 1-7.

6. Fisher J.W. Erytropoietin, In Massry S.G., Glassock R.J., Textbook of Nephrology, 3rd Edition, Williams \& Wilkins, Baltimore, Maryland USA, 1995; 191- 197.

7. Ghezi $P$, Brines M. Erythropoietin as an antiapoptotic, tissue-protective cytokine. Cell Death and Differentiation 2004; 11: 37-44.

8. BakerJE. Erythropoietin mimics ischemic preconditioning. Pharmacology and Toxicology, Biochemistry and Pediatric Surgery, Medical College of Wisconsin, 8701 Watertown Plank Road, Milwaukee, WI 53226, USA. 2005; 42 (5-6): 233-41.

9. Villa P, Sartor G, Angelini M, et al. Pattern of cytokines and pharmacomodulation in sepsis induced by cecal ligation and puncture compared with that induced by endotoxin. Clin Diagn Lab Immunol 1995; 2: 549-553.

10. Pascual J, Teruel JL, Moya JL, Liaño F, Jiménez-Mena M, Ortuño J. Regression of left ventricular hypertrophy after partial correction of anemia with erythropoietin in patients on hemodialysis: a prospective study. Clin Nephrol. 2008;280-7.

11. Maiese K, Li F, Chong ZZ. New avenues of exploration for erythropoietin. JAMA. 2005; 293: 90-95.
12. Vedat Bakan, Harun Çıralık, Fatma Inanaç Tolun, Yalçın Atlı, Ayhan Mil , Senol Öztürk: Protective effect of erythropoietin on torsion/detorsion injury in rat model. Journal of Pediatric Surgery, 2009; 44: 1988-1994.

13. M. Bockhorn, C. Fingas, E. Niehues, M. Trippler, A. Frilling, C. E. Broelsch, J. F. Schlaak, exogenous administiration of erythropoetin improves liver regeneration of the donor and recipient in a rat living related liver transplantation model. General and Transplantation Surgery; Gastroenterology and Hepatology, University@ Hospital Essen, Essen, Parallel Session 4: Liver failure and transplantation 2007; 4: 16-17.

14. Sepodes B, Maio R, Pinto R, Sharples E, Oliveira $P$, McDonald $M$, Yaqoob $M$, Thiemermann C, Mota-Filipe H: Recombinant human erythropoietin protects the liver from hepatic ischemia-reperfusion injury in the rat. Transpl Int 2006; 19: 919- 926.

15. Aoshiba K, Onizawa S, Tsuji T, Nagai A. Therapeutic effects of erythropoietin in murine models of endotoxin shock. First Department of Medicine, Tokyo Women's Medical University, Tokyo, Japan. Crit Care Med. 2010; (1): 340-341.

16. Rocha J, Eduardo-Figueira $M$, Barateiro $A$, Fernandes A, Brites D, Pinto R. Erythropoietin Reduces Acute Lung Injury and Multiple Organ Failure/Dysfunction Associated to a Scald-Burn Inflammatory Injury in the Rat Inflammation 2014, published online: 1 October 2014, (DOI: 10.1007/s10753-014-0035-7).

17. Mesut Gul, Mustafa Cömert, Güldeniz Karadeniz Çakmak, Gurkan Kertis, Ebru Ugurbas, Muzaffer Onder Oner. Effect of erythropoietin on liver regeneration in an experimental model of partial hepatectomy International Journal of Surgery 2013; (11): 59-63.

18. Nandra K.K, Collino M, Rogazzo M, Fantozzi R, Patel N, Thiemermann C. Pharmacological preconditioning with erythropoietin attenuates the organ injury and dysfunction induced in a rat model of hemorrhagic shock. Disease Models \& Mechanisms 2013; (6): 701-709. 